\title{
PENGARUH PENDIDIKAN KELUARGA TERHADAP PRESTASI
}

\author{
BELAJAR
}

\author{
Suparman, S.Pd, M.Si
}

Pengukuran Pendidikan

Dosen Pada Program Studi PAI STAIMS Yogyakarta

tsabita.bita@gmail.com

Khusnan Kusumawati, S.Pd

Operator dapodik Sekolah Dasar Negeri Ngijon II, Moyudan

kusumawati_khusnan@yahoo.com

\begin{abstract}
ABSTRAK
Artikel ini bertujuan untuk mengetahui pengaruh pendidikan dalam keluarga terhadap prestasi belajar peserta didik di SD N Ngijon, Sleman, Yogyakarta. Prestasi belajar peserta didik meliputi kemampuan kognitif, kemampuan afektif dan kemampuan psikomotor. Pendidikan dalam keluarga sebagai variabel $\mathrm{X}$ atau prediktor dan prestasi belajar peserta didik sebagai variabel $\mathrm{Y}$ atau kriterium.

Data diperoleh dengan observasi, dokumentasi dan membagikan angket. Penelitian ini menggunakan 19 subjek penelitian yang berasal dari Sekolah Dasar Negeri Ngijon II, Moyudan, Sleman, Yogyakarta. Oleh karena jumlah subjek sebanyak 19 maka penelitian ini bersifat populatif. Sedangkan analisis data menggunakan tehnik korelasi produk momen, regresi linier, serta tehnik statistik deskriptif.

Hasil penelitian menunjukakan bahwa terbukti adanya pengaruh dari pendidikan dalam keluarga terhadap prestasi belajar peserta didik. Berdasarkan analisis regresi diperoleh nilai $R^{2}$ sebesar 0,45 yang berarti bahwa pendidikan dalam keluarga mempengaruhi keberhasilan belajar peserta didik sebesar $45 \%$. Nilai $\mathrm{R}^{2}$ sebesar 0,45 ini merupakan hasil temuan yang signifikan berdasarkan uji analisi varian yang memperoleh nilai t sebesar 0,0012.
\end{abstract}

\section{Kata kunci : peserta didik, prestasi belajar, korelasi, regresi.}

\section{ABSTRACT}

This article aims to investigate the influence of education in the family on the learning achievement of students at State Elementary School II Ngijon, Moyudan, Sleman, Yogyakarta. Achievement of learners includes cognitive ability, the ability of affective and psychomotor ability. Education within the family as $X$ or predictor variables and the achievement of learners as a variable $Y$ or criterion. 
Suparman : Pengaruh Pendidikan Keluarga Terhadap Prestasi Belajar

Data obtained by observation, documentation and distribute questionnaires. This study uses 19 research subjects are derived from State Elementary School Ngijon II, Moyudan, Sleman, Yogyakarta. Therefore the number of subjects were 19 then this study is populatif. While data analysis using product moment correlation technique, linear regression, as well as descriptive statistical techniques.

The results showed that proved the influence of education in the family of the achievements of learners. Based on regression analysis $R 2$ value of 0.45 , which means that the education in the family affects the success of learners by $45 \%$. R2 value of 0.45 is the result of significant findings based on analysis of test variants obtained t value of 0.0012 .

Keywords: students, school performance, correlation,
regression.

\section{A. Pendahuluan}

Perkembangan zaman menjadi salah satu penyebab bergesernya nilai-nilai budaya dan berdampak pada berubahnya tatanan kehidupan pada masayarakat. Perubahan ini dapat dirasakan secara fisik maupun sosial. Proses perubahan sosial dirasakan terutama pada interaksi keluarga. Fenomena tersebut terjadi karena tuntutan kebutuhan hidup dan gaya hidup, akhirnya banyak keluarga yang kedua orang tuanya bekerja untuk memenuhi kebutuhan keluarga. Implikasinya sebagian besar waktunya banyak digunakan untuk bekerja, sehingga mengurangi perhatian dan bimbingan terhadap anak-anak.

Keluarga adalah sekelompok orang yang terdiri dari kepala keluarga dan anggotanya dalam ikatan nikah ataupun nasab yang hidup dalam satu tempat tinggal, memiliki aturan yang ditaati secara bersama dan mampu mempengaruhi antar 
anggotanya serta memiliki tujuan dan program yang jelas. ${ }^{1}$ Keluarga merupakan lingkungan pertama bagi anak, di lingkungan keluarga pertama mendapatkan pengaruh, karena itu keluarga merupakan lembaga pendidikan tertua, yang bersifat informal dan kodrati. ${ }^{2}$

Kesibukan orang tua dalam bekerja menyebabkan keluarga tersebut menyerahkan sepenuhnya pendidikan anak kepada lembaga pendidikan formal yaitu sekolah, dengan harapan anak-anak mereka mendapatkan pendidikan yang seutuhnya baik ilmu agama maupun ilmu pengetahuan umum lainnya. Penghasilan yang diperoleh orang tua sebagian besar untuk memenuhi kebutuhan anak-anaknya, namun karena frekuensi bekerja yang banyak maka interaksi dengan anak-anaknya semakin kecil sehingga anak-anak merasa kurang mendapat kasih sayang dari orang tuanya. Anak-anak dipenuhi kebutuhan fisiknya, akan tetapi kurang terpenuhi kebutuhan akan kasih sayang.

Latar belakang pendidikan orang tua yang belum memadai, menyebabkan sering terjadinya hal-hal yang tidak diharapkan seperti pertengkaran, perselingkuhan, kekerasan dalam rumah tangga (KDRT) dan perceraian. Semua kejadian tersebut akan mempengaruhi perkembangan bagi anakanaknya. Anak-anak tumbuh dan berkembang pada suasana rumah tangga yang tidak ideal. Anak-anak memiliki kebiasaan yang tidak baik di rumah maupun di sekolah, seperti berkata bohong, suka menipu, membolos, mencuri, salah pergaulan dan lain sebagainya.

1 Safrudin Aziz, Pendidikan Keluarga Konsep dan Strategi, (Yogyakarta: Gava Media, 2015), hlm. 16-17

2 Jalaluddin, Psikologi Agama, (Jakarta: PT RajaGrafindo Persada, 2010), hlm. 294 
Suparman : Pengaruh Pendidikan Keluarga Terhadap Prestasi Belajar

Masalah yang dialami anak di rumah sebagai akibat perhatian orang tua yang kurang kepada anak akan terbawa di sekolah. Persoalan di sekolah dapat terjadi dalam bentuk masalah berhubungan dengan sesama peserta didik, masalah peserta didik dengan sekolah bahkan bisa juga terjadi antara peserta didik pada sekolah yang lain. Dengan demikian sebagian persoalan peserta didik dalam pendidikan, bersumber dari persoalan di rumah.

Tidak jarang terjadi menurunnya prestasi belajar peserta didik, disebabkan kurangnya pengetahuan orang tua akan pentingnya pendidikan di rumah.

\section{B. Tujuan Penelitian}

Berangkat dari latar belakang di atas, maka penelitian ini bertujuan untuk mengetahui hal-hal yang berkaitan dengan pendidikan keluarga dan prestasi belajar peserta didik di Sekolah Dasar Negeri II Moyudan Sleman. Adapun secara verbal, rumusan dari penelitian ini dapat disusun menjadi :

Pertama, mengetahui tingkat pemahaman pendidikan keluarga peserta didik di SDN Ngijon II Moyudan Sleman.Pemahaman pendidikan keluarga secara teoritis akan mempengaruhi prestasi peserta didik. Hal ini disebabkan karena keluarga merupakan lingkungan pertama bagi anakanak untuk belajar. Keluarga yang memiliki pemahaman tentang pendidikan akan lebih kondusif untuk belajar.

Kedua, Mengetahui prestasi belajar peserta didik di SDN Ngijon II Moyudan Sleman, Pemahaman keluarga tentang pendidikan, secara teoritis berhubungan dengan prestasi belajar, akan tetapi sebagai bentuk konfirmasi teori tersebut apakah secara fakta dapat ditemui dilapangan? Tujuan ini berusaha menjelaskannya. 
Ketiga, mengetahui pengaruh pendidikan keluarga terhadap prestasi belajar peserta didik SDN Ngijon II Moyudan Sleman, dengan mengetahui koefisien regresi antara pemahaman pendidikan terhadap prestasi belajar anak, maka dapat diestimasi tingkat prestasi belajar anak dari pemahaman pendidikan keluarga orang tuaanya.

\section{Tinjauan Teoritis}

Ayah dan Ibu dalam keluarga sebagai pendidiknya, dan anak sebagai peserta didiknya. Keluarga merupakan pendidikan informal. Tugas keluarga adalah meletakkan dasar-dasar bagi perkembangan bagi anak berikutnya, agar anak dapat berkembang secara baik. Anak yang karena satu dan lain hal tidak mendapatkan pendidikan dasar secara wajar ia mengalami kesulitan dalam perkembangan berikutnya. Keluarga sebagai lingkungan pendidikan yang pertama sangat penting membentuk pola kepribadian anak, karena di dalam keluarga anak pertama kali berkenalan dengan nilai dan norma. ${ }^{3}$

Keluarga adalah tempat titik tolak perkembangan anak. Peran keluarga sangat dominan untuk menjadikan anak yang cerdas, sehat, dan memiliki penyesuaian sosial yang baik. Keluarga adalah institusi sosial yang ada dalam setiap masyarakat. ${ }^{4}$ Keluarga adalah lembaga pendidikan informal (luar sekolah) yang diakui keberadaannya dalam dunia pendidikan. Peranannya tidak kalah pentingnya dari lembaga formal dan non-formal. Bahkan sebelum anak didik memasuki suatu sekolah, dia sudah mendapatkan pendidikan dalam keluarga yang bersifat kodrati. Hubungan darah antara

3 Nur Ahid, Pendidikan Keluarga dalam Perspektif Islam, (Jakarta: Pustaka Pelajar, 2010), hlm. 99-100

4 Helmawati, Op.Cit, hlm. 49-50 
Suparman : Pengaruh Pendidikan Keluarga Terhadap Prestasi Belajar

kedua orang tua dengan anak menjadikan keluarga sebagai lembaga pendidikan yang alami. ${ }^{5}$

Keluarga merupakan tempat yang penting bagi perkembangan anak secara fisik, emosi, spiritual, dan sosial. Keluarga sumber bagi kasih sayang, perlindungan, dan identitas bagi anggotanya. Keluarga menjalankan fungsi yang penting bagi keberlangsungan masyarakat dari generasi ke generasi. 6

Kebiasaan anak yang buruk di sekolah secara individu meyebabkan kesiapan mengikuti pelajaran, perhatian terhadap materi pembelajaran, dan kemampuan menyerap materi belajar menjadi berkurang. Secara keseluruhan, anakanak memiliki prestasi belajar yang rendah. Rendahnya prestasi belajar yang terjadi secara masif dan pada rentang waktu yang panjang akan menjadi rendahnya kualitas sumber daya manusia yang pada akhirnya nanti dapat menjadi masalah secara nasonal.

1. Fungsi Keluarga

Keluarga memiliki fungsi yang saling terkait antara fungsi satu dengan fungsi yang lainnya. Keterkaitan itu pada prinsipnya sebagai wahana untuk mengembangkan seluruh potensi anggotanya agar dapat menjalankan fungsinya di masyarakat dengan baik serta memberikan kepuasan dan lingkungan sosial yang sehat guna tercapainya keluarga sejahtera. ${ }^{7}$ Keluarga memiliki lima fungsi dasar, yaitu:

5 Syaiful Bahri Djamarah, Psikologi Belajar, (Jakarta: PT Rineka Cipta, 2011), hlm. 241

6 Sri Lestari, Psikologi Keluarga, (Jakarta: Kencana, 2014), hlm. 22

7 Safrudin Aziz, Op.Cit, hlm. 19 
a. Reproduksi, keluarga memiliki tugas untuk mempertahankan populasi yang ada dalam masyarakat.

b. Sosialisasi/edukasi, keluarga menjadi sarana untuk transmisi nilai, keyakinan, sikap, pengetahuan, keterampilan, dan teknik dari generasi sebelumnya ke generasi yang lebih muda.

c. Penugasan peran sosial, keluarga memberikan identitas pada para anggotanya seperti ras, etnik, religi, sosial ekonomi, dan peran gender.

d. Dukungan ekonomi, keluarga menyediakan tempat berlindung, makanan, dan jasmani kehidupan.

e. Dukungan emosi/ pemeliharaan, keluarga memberikan pengalaman interaksi sosial yang pertama bagi anak. Interaksi yang terjadi bersifat mendalam, mengasuh, dan berdaya tahan sehingga memberikan rasa aman pada anak. ${ }^{8}$

Fungsi - fungsi dalam keluarga yang hendaknya dilaksanakan agar tercipta keluarga bahagia yang didambakan. Fungsi yang hendaknya dihadirkan dalam keluarga adalah fungsi agama, fungsi biologis, fungsi ekonomi, fungsi kasih sayang, fungsi perlindungan, fungsi pendidikan, fungsi sosialisasi anak, dan fungsi rekreasi. ${ }^{9}$

2. Pendidikan dalam Keluarga

Lembaga Pendidikan keluarga merupakan lembaga pendidikan yang pertama, tempat anak didik pertama-tama menerima pendidikan dan bimbingan dari orang tuanya atau anggota keluarga lainnya. Di dalam keluarga inilah tempat meletakkan dasar-dasar kepribadian anak didik

8 Sri Lestari, Op.Cit, hlm. 22

9 Helmawati, Op.Cit, hlm. 45-48 
pada usia yang masih muda, karena pada usia-usia ini anak lebih peka terhadap pengaruh dari pendidiknya (orang tuanya dan anggota yang lain). ${ }^{10}$

Pendidikan dalam keluarga merupakan pendidikan yang bersifat pembiasaan, spontanitas, unik dan mengesankan. Pendidikan keluarga merupakan pendidikan organik, materi pendidikannya berisi pengalaman kehidupan, media dan metodenya disesuaikan dengan keadaan atau kondisi setiap keluarga tanpa harus memerlukan biaya yang besar serta pengajar yang formal bahkan bisa dilakukan dalam waktu 24 jam. Pendidikan keluarga pada hakikatnya merupakan fungsi dari institusi keluarga itu sendiri yang harus terlaksana secara menyeluruh. Sehingga anggota keluarga memiliki pengalaman yang banyak yang diperoleh dari proses pendidikan yang dilaksanakan. Pendidikan keluarga mencakup berbagai ruang lingkup dan nilai yang tercipta secara alami dalam kehidupan sehari-hari. ${ }^{11}$

Pendidikan merupakan kegiatan yang sangat esensial dalam kehidupan manusia untuk membentuk insan yang dapat memecahkan permasalahan dalam kehidupannya. William J. Goode (1995) mengemukakan bahwa keberhasilan atau prestasi yang dicapai siswa dalam pendidikannya sesungguhnya tidak hanya memperhatikan mutu dari institusi pendidikan saja, tetapi juga memperlihatkan keberhasilan keluarga dalam memberikan anak-anak mereka persiapan yang baik untuk pendidikan yang dijalani. Dijelaskan dalam pasal 27 bahwa kegiatan

10 Zuhairini, Filsafat Pendidikan Islam, (Jakarta: Bumi Aksara, 2009), hlm. 177

11 Safrudin Aziz, Op.Cit, hlm. 20-22 
pendidikan informal yang dilakukan oleh keluarga dan lingkungan berbentuk kegiatan belajar secara mandiri. Pendidikan keluarga memberikan pengetahuan dan keterampilan dasar, agama dan kepercayaan, nilai-nilai moral, norma sosial dan pandangan hidup yang diperlukan anak. ${ }^{12}$

Pendidikan keluarga adalah juga pendidikan masyarakat, karena disamping keluarga itu sendiri sebagai kesatuan kecil dari bentuk kesatuan-kesatuan masyarakat, juga karena pendidikan yang diberikan oleh orang tua kepada anak-anaknya sesuai dan dipersiapkan untuk kehidupan anak-anak itu di masyarakat kelak. Seseorang akan menjadi warga masyarakat yang baik sangat tergantung pada sifat-sifat yang tumbuh dalam kehidupan keluarga di mana anak dibesarkan. Kelak, kehidupan anak tersebut juga mempengaruhi masyarakat sekitarnya sehingga pendidikan keluarga itu merupakan dasar terpenting untuk kehidupan anak sebelum masuk sekolah dan terjun ke masyarakat. ${ }^{13}$

3. Dasar Pendidikan Keluarga

Dasar adalah landasan tempat berpijak atau tempat tegaknya sesuatu. Dalam hubungannya dengan pendidikan keluarga, dasar-dasar itu merupakan pegangan untuk memperkokoh nilai-nilai yang terkandung di dalamnya. Adapun yang menjadi dasar pendidikan keluarga adalah AlQur'an dan Hadis.

a. Al-Qur'an

12 Helmawati, Op.Cit, hlm. 49-50

13 Abu Ahmadi dan Nur Uhbiyati, Imu Pendidikan, (Jakarta: Rineka Cipta, 2015), hlm. 178 
Kedudukan Al-Qur'an sebagai dasar pendidikan keluarga dapat dipahami dalam ayat Al-Qur'an diantaranya terdapat dalam surah At-Tahrim ayat ke 6 dan surah Luqman ayat ke 13. Yaitu :

Surah At-Tahrim, ayat ke 6 :

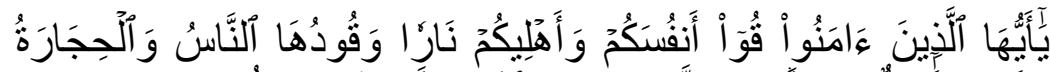

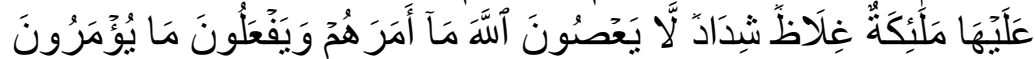

Artinya: "Hai orang-orang yang beriman, peliharalah dirimu dan keluargamu dari api neraka yang bahan bakarnya adalah manusia dan batu; penjaganya malaikat-malaikat yang kasar, keras, dan tidak mendurhakai Allah terhadap apa yang diperintahkanNya kepada mereka dan selalu mengerjakan apa yang diperintahkan. ${ }^{14}$

Surah Luqman, ayat ke 13 :

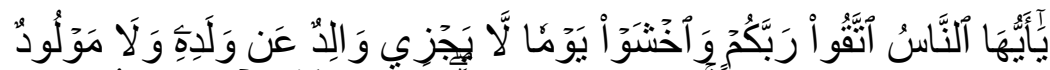

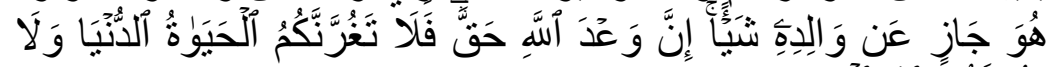

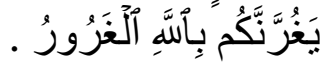

Artinya: "dan (ingatlah) ketika Luqman berkata kepada anaknya, di waktu ia memberi pelajaran kepadanya: "Hai anakku, janganlah kamu mempersekutukan Allah, Sesungguhnya mempersekutukan (Allah) adalah benarbenar kezaliman yang besar". 15

14 Syamil Al-Qur'an, Al-Qur'anul Karim Special for Women, (Bandung: Sygma Examedia Arkanleema, 2009), hlm. 560

15 Ibid, hlm. 412 
b. Hadits

Hadis adalah segala sesuatu yang diidentikan kepada Nabi Muhammad SAW, berupa perkataan, perbuatan dan taqrirnya, ataupun selain dari itu. Adapun hadits yangberkaitan dengan pendidikan keluarga diantaraanya adalah :

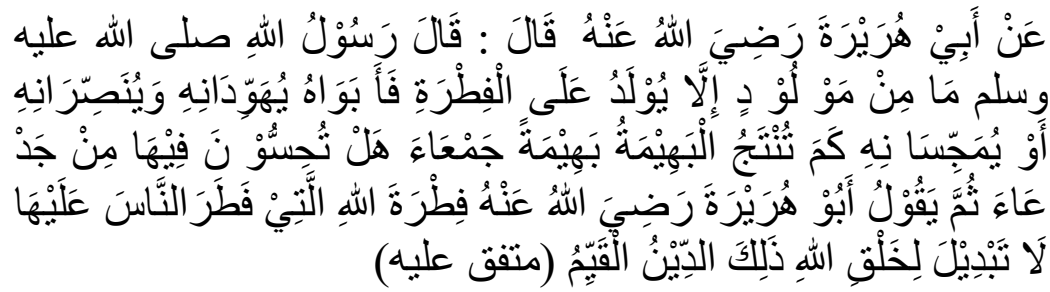

Artinya : Dari Abu Hurairah r.a. berkata, Rasulullah Saw. Bersabda: "Tidak ada dari seorang anak (Adam) melainkan dilahirkan atas fitrah (islam), maka kedua orang tuanyalah yang menjadikannya beragama Yahudi atau beragama Nasrani atau beragama Majusi. Bagaikan seekor binatang yang melahirkan seekor anak. Bagaimana pendapatmu, apakah didapati kekurangan? Kemudian Abu Hurairah membaca firman Allah (Q.S. arRum: 30). (Tetaplah atas) fitrah Allah yang telah menciptakan manusia menurut fitrah itu. Tidak ada perubahan pada fitrah Allah (agama Allah). (HR. Muttafaq 'Alaih). ${ }^{16}$

\section{Prestasi Belajar Peserta Didik}

Prestasi belajar adalah apa yang telah dicapai oleh siswa setelah melakukan kegiatan belajar. Pencapaian prestasi belajar atau hasil belajar siswa, merujuk kepada aspek-aspek kognitif, afektif, dan psikomotor. Oleh karena itu, ketiga aspek di atas juga harus menjadi indikator

16 Abdul Majid Khon, Hadis Tarbawi, (Jakarta: Kencana Prenada Media Grup, 2012), hlm. 67 
prestasi belajar. Artinya, prestasi belajar harus mencakup aspek-aspek kognitif, afektif, psikomotor. ${ }^{17}$

Prestasi adalah hasil dari pembelajaran. Prestasi juga dapat dikatakan sebagai hasil dari perubahan akibat belajar. Terlepas dari angka yang diperoleh, ketika anak belajar sesuatu dari tidak bisa menjadi bisa maka ia dapat dikatakan berprestasi. Prestasinya adalah perubahan itu sendiri. Anak yang tadinya selalu mendapat angka di bawah KKM (kriteria ketuntasan minimal/ batas minimal yang harus diperolehnya dalam materi tertentu), kemudian ia memperoleh nilai di atas KKM meskipun bukan angka sempurna, ia dapat dikatakan telah berprestasi. 18

Prestasi belajar yang dicapai peserta didik satu dengan yang lain bisa jadi berbeda, semua tergantung dari potensi (kecerdasan) yang dimilikinya. Jika anak memiliki potensi yang menonjol dalam suatu kecerdasan, kemungkinan besar ia akan mencapai prestasi yang dalam bidang tersebut. Prestasi dapat dikatakan sebagai hasil dari perubahan perilaku belajar. Perilaku belajar seseorang dapat dilihat dari ciri-ciri perubahan yang spesifik, yaitu: perubahan psikomotorik, perubahan afektif, dan perubahan kognitif. ${ }^{19}$

Manifestasi atau perwujudan prestasi belajar biasanya lebih sering tampak dalam perubahan-perubahan, yaitu:

a. Kebiasaan, peserta didik yang berhasil dalam proses belajarnya akan menampakkan perubahan berupa

17 Tohirin, Psikologi Pembelajaran Pendidikan Agama Islam, (Jakarta: RajaGrafindo Persada, 2011), hlm.151

18 Helmawati, Op.Cit, hlm. 205-206

19 Ibid, hlm. 207-208 
kebiasaan-kebiasaan ke arah yang baik atau lebih baik lagi. Anak yang dibiasakan untuk tidak berbohong akan terbiasa berkata jujur.

b. Keterampilan, yaitu kegiatan yang berhubungan dengan urat syaraf dan otot yang bersifat motorik. Kegiatan ini membutuhkan koordinasi gerak yang teliti dan memerlukan kesadaran yang tinggi.

c. Pengamatan, yang dapat diartikan sebagai proses menerima, menafsirkan dan mengartikan rangsangan yang masuk melalui pancaindra, terutama mata dan telinga.

d. Berpikir asosiatif dan daya ingat, maksudnya menjadikan dirinya berpikir untuk menghubungkan sesuatu dengan sesuatu lainnya dan meningkatkan daya ingat.

e. Berpikir rasional dan kritis, adalah perwujudan perilaku belajar terutama yang berhubungan dengan pemecahan masalah, menggunakan logika untuk menentukan sebab-akibat, menganalisis, menyimpulkan, bahkan meramalkan sesuatu.

f. Sikap, ditandai dengan munculnya kecenderungan baru dalam diri seseorang dalam menghadapi suatu objek, tata nilai, peristiwa, dan sebagainya.

g. Inhibisi, pada konteks belajar dapat diartikan kesanggupan anak untuk mengurangi atau menghentikan tindakan yang tidak perlu dan mampu memilih atau melakukan tindakan lain yang lebih baik.

h. Apresiasi, adalah gejala ranah afektif yang pada umumnya ditunjukkan pada karya-karya seni budaya, 
seperti seni sastra, seni musik, seni lukis, drama, dan sebagainya.

i. Tingkah laku afektif, adalah tingkah laku yang menyangkut keanekaragaman perasaan, seperti takut, marah, sedih, gembira, kecewa, senang, benci, was was, dan sebagainya. ${ }^{20}$

Oleh karena itu peserta didik dikatakanbelajar apabila telah terjadi perubahan dalam berfikir, bertindak dan bersikap. Adanya perubahan ini tidak lepas dari interaksi yang bermakna antara pembelajaran di rumah maupun di sekolah.

5. Faktor yang Mempengaruhi Belajar

Prestasi belajar yang dicapai seseorang merupakan hasil interaksi berbagai faktor yang mempengaruhinya baik dari dalam diri (faktor internal) maupun dari luar diri (faktor eksternal) individu. Pengenalan terhadap faktorfaktor yang mempengaruhi prestasi belajar penting sekali artinya dalam rangka membantu peserta didik dalam mencapai prestasi belajar yang sebaik-baiknya. ${ }^{21}$ Prestasi belajar yang memuaskan dapat diraih oleh setiap peserta didik jika mereka dapat belajar secara wajar, terhindar dari berbagai ancaman, hambatan dan gangguan. ${ }^{22}$

Secara global, faktor - faktor yang mempengaruhi prestasi belajar siswa dapat dibedakan menjadi tiga macam, yaitu:

a. Faktor Internal Siswa, yakni faktor yang berasal dari dalam diri siswa sendiri meliputi dua aspek, yaitu : (1)

20 Lilik Sriyanti, Psikologi Belajar, (Yogyakarta: Ombak, 2013), hlm. 2224

21 Widodo Supriyono, Psikologi Belajar, (Jakarta: PT Rineka Cipta, 2013), hlm. 138

22 Syaiful Bahri Djamarah, Op.Cit, hlm. 233 
aspek fisiologis, (2) aspek psikologis, meliputi inteligensi, sikap, bakat, minat, motivasi intriksik dan motivasi ekstrinsik. ${ }^{23}$

b. Faktor Eksternal yaitu keadaan lingkungan yang dapat mempengaruhi seseorang dalam berprestasi. ${ }^{24}$ Keadaan lingkungan dibagi menjadi dalam dua kategori, yaitu: lingkungan sosial dan non sosial.

Lingkungan Sosial meliputi keluarga, sekolah, dan masyarakat. 25 Adapun lingkungan non social meliputi lingkungan tempat tinggal/ belajar, alat-alat belajar, keadaan cuaca (alam), waktu belajar. ${ }^{26}$

\section{Metode Penelitian}

Data yang digunakan dalam penelitian ini bersifat kuantitatif. Data diperoleh dengan tiga metode yaitu dokmentasi, wawamcara, dan kuasioner. Ketiga metode pengumpulan data tersebut dapat dijelaskan sebagai berikut :

Dokumentasi, yakni mencari data mengenai hal-hal atau variabel yang berupa catatan, transkip, buku, surat kabar, majalah, prasasti, notulen rapat, lengger, agenda, dsb. ${ }^{27}$ Dokumen merupakan catatan peristiwa yang sudah berlalu bisa berbentuk tulisan, gambar, atau karya-karya monumental. 28 Penulis menggunakan dokumentasi untuk memperoleh data guru, data peserta didik, sejarah sekolah, visi dan misi sekolah.

23 Muhibbin Syah, Psikologi Pendidikan, (Bandung: PT Remaja Rosdakarya, 2014), hlm. 129

24 Muhibbin Syah, Op.Cit, hlm. 130-133

25 Ibid, hlm. 134

26 Ibid, hlm. 135

27 Suharsimi Arikunto, Prosedur Penelitian Suatu Pendekatan Praktik, (Jakarta: Rineka Cipta, 2010), hlm. 274

28 Sugiyono, Metode Penelitian Kombinasi, (Bandung: Alfabeta, 2012), hlm. 326 
Suparman : Pengaruh Pendidikan Keluarga Terhadap Prestasi Belajar

Wawancara (Interview) adalah sebuah dialog yang dilakukan oleh pewawancara untuk memperoleh informasi dari terwawancara. 29 Metode ini digunakan untuk memperoleh data sekolah yang diperlukan untuk kelengkapan dalam penelitian.

Kuesioner suatu alat pengumpul informasi dengan cara menyampaikan sejumlah pertanyaan tertulis untuk menjawab secara tertulis pula oleh responden. 30

Kuesioner merupakan metode pengumpulan data yang dilakukan dengan cara memberi seperangkat pertanyaan atau pernyataan tertulis kepada responden untuk dijawab. Kuesioner merupakan teknik pengumpulan data yang efisien bila peneliti tahu dengan pasti variabel yang akan diukur dan tahu apa yang biasa diharapkan. ${ }^{31}$

Metode ini digunakan untuk memperoleh data tentang pendidikan dalam keluarga dan prestasi belajar peserta didik kelas V SDN Ngijon II Moyudan Sleman.

Data yang diperoleh dengan metode kuesioner berupa skor dengan skala 4 pada skala likert tentang pemahaman pendidikan keluarga (variabel X) dan prestasi belajar anak (variabel Y). Adapun indikator dari pemahaman keluarga adalah pentingnya pendidikan, tingkat sosial ekonomi, kehidupan beragama dan pola komunikasi. Adapun indikator dari prestasi belajar meliputi perubahan psikomotor, afektif dan kognitif peserta didik selama mengikuti kegiatan pembelajaran di sekolah.

29 Suharsimi Arikunto, Op.Cit, hlm. 198

30 Margono, Metodologi Penelitian Pendidikan, ( Jakarta: Rineka Cipta, 2004 ), hlm. 165

31 Sugiyono, Op. Cit, hlm. 192 
Akurasi pengukuran dilakukan dengan memilih koefisien validitas dan reliabilitas butir pernyataan dari setiap indikator yang telah ditentukan. Butir yang valid dan reliabel digunakan dalam proses analisis data, adapun butir yang tidak valid dan tifak reliabel tidak diikutkan pada analisis.

Suatu butir instrumen dikatakan valid apabila memiliki sumbangan yang besar terhadap skor total. Dengan kata lain dikatakan mempunyai validitas yang tinggi jika skor pada butir mempunyai kesejajaran dengan skor total. Kesejajaran ini dapat diartikan dengan korelasi, sehingga untuk mengetahui validitas butir digunakan rumus korelasi product moment. ${ }^{32}$ Uji validitas sebaiknya dilakukan pada setiap butir pertanyaan/ pernyataan. Hasil $r$ hitung kita bandingkan dengan $r$ tabel dimana $\mathrm{df}=\mathrm{n}-2$ dengan taraf signifikansi $5 \%$. Jika $\mathrm{r}$ tabel $<\mathrm{r}$ hitung maka valid. ${ }^{33}$ Rumus korelasi product moment dengan angka kasar, yakni :

$$
r_{x y}=\frac{N \sum X Y-\left(\sum X\right)\left(\sum Y\right)}{\sqrt{\left.\left\{N \sum X^{2}-\left(\sum X\right)^{2}\right)\right\}\left\{N \sum Y^{2}-\left(\sum Y\right)^{2}\right\}}}
$$

Koefisien reliabilitas ditentukan dengan menggunakan rumus Alpha, ${ }^{34}$ yaitu :

$$
r_{11}=\left[\frac{n}{n-1}\right]\left[1-\frac{\sum \sigma_{i}^{2}}{\sigma_{t}^{2}}\right]
$$

Cara ini ditempuh untuk mempertinggi ketepatan dari kesimpulan yang diperoleh.

Analisis selanjutnya adalah menguji asumsi bahwa skor pemahaman pendidikan keluarga dan skor prestasi belajar bersifat normal dan linier Normalitas dicari dengan rumus :

32 Eko Putro Widoyoko, Teknik Penyusunan Instrumen Penelitian, (Yogyakarta: Pustaka Pelajar, 2014), hlm. 147

33 Wiratna Sujarweni, Op.Cit, hlm. 187

34 Eko Putro Widoyoko, Op.Cit, hlm. 159-163 
Suparman : Pengaruh Pendidikan Keluarga Terhadap Prestasi Belajar

$$
\chi^{2}=\frac{\sum(f o-f h)^{2}}{f h}
$$

Keterangan :

$\mathrm{F} \quad$ : Nilai F hitung

$s_{1}{ }^{2}:$ Nilai varian terbesar

$S_{2}{ }^{2}:$ Nilai varian terkecil 35

Sedangkan linieritas dicari dengan uji F, yakni :

$$
\mathrm{F}=\frac{S_{1}{ }^{2}}{S_{2}{ }^{2}}
$$

adapun homoginitas dicari dengan uji t. Setelah data bersifat linier dan homogen, analisis dilanjutkan dengan mencari pengaruh pemahaman pendidikan keluarga terhadap prestasi belajar.

Analisis selanjutnya adalah mencari pengaruh variabel $\mathrm{X}$ (pendidikan Keluarga) terhadap Y (Prestasi Belajar) dengan menggunakan regresi sederhana, dimana pola regresi didasarkan pada hubungan fungsional ataupun kausal satu variabel dependen. ${ }^{36}$

$$
\text { Rumus : } \mathrm{Y}=\mathrm{a}+\mathrm{bX}
$$

Keterangan:

Y : Subyek dalam variabel dependen yang diprediksikan

a : (Prestasi Belajar). Harga Y ketika harga $\mathrm{X}=0$

b : (harga konstan). Angka arah atau koefisien regresi, yang menunjukkan angka peningkatan ataupun penurunan variabel dependen yang didasarkan pada perubahan variabel independen.

35 Sugiyono, Op. Cit, hlm. 275

36Sugiyono, Statistika untuk Penelitian, (Bandung: Alfabeta, 2013), hlm. 
$\mathrm{X}$ : Subyek pada variabel independen yang mempunyai nilai tertentu (Pendidikan Keluarga). 37

\section{E. Pengajuan Hipotesis}

Hipotesis dalam penelitian ini dapat dirumuskan bahwa Pendidikan Keluarga memiliki pengaruh yang signifikan terhadap Prestasi Belajar Peserta Didik

\section{F. Hasil Penelitian}

Berdasarkan uji analisis instrument dapat diketahui bahwa setiap butir instrument yang digunakan dalam penelitian ini merupakan butir yang valid. Instrumen pada Pendidikan Keluarga (Variabel $\mathrm{X}$ ) berjumlah 27 butir pernyataan. Melalui uji validitas dapat diketahui bahwa 27 butir pertanyaan dikategorikan sebagai instrument yang valid. Rekapitulasi validitas dapat dilihat pada tabel 1, dengan demikian dapat diambil pengertian bahwa butir pernyataan untuk variabel Pendidikan Keluarga adalah butir pernyataan yang dapat dipertanggungjawabkan secara statistik.

Instrument untuk Prestasi Belajar ( Variabel Y) berjumlah 31 butir pernyataan. Melalui uji validitas dapat diketahui bahwa 31 butir pertanyaan dikategorikan sebagai instrument yang valid. Rekapitulasi validitas dapat dilihat pada tabel 2, dengan demikian dapat diambil pengertian bahwa butir pernyataan untuk variabel Prestasi Belajar adalah butir pernyataan yang dapat dipertanggungjawabkan secara statistik.

Instrument selain memiliki validitas yang baik juga harus memiliki reliabilitas atau konsistensi instrument unruk mengukur variabel tertentu. Koefisien reliabilitas dihitung dengan formulasi koefisien alpha diperoleh angka sebesar 
0,941 untuk variabel Pendidikan Keluarga dan sebesar 0,954 untuk variabel Prestasi Belajar, sehingga instrument ini disebut dengan instrument yang reliabel.

Berdasarkan pada hasil analisis validitas dan reliabilitas, maka dapat disebutkan bahwa instrument yang digunakan dalam penelitian ini adalah instrument yang valid dan reliabel, dengan demikian skor yang diperoleh dengan menggunakan instrument ini dapat dipertanggungjawabkan secara statistik.

Hasil uji asumsi menunjukkan bahwa data yang terdapat pada penelitian ini merupakan data yang bersifat normal dan linier. Oleh karena data bersifat normal dan linier maka dapat dilanjutkan pada tahap selanjutnya yakni analisis regresi, karena telah memenuhi persyaratan.

Normalnya suatu data atau seringdisebut normalitas menunjukakan bahwa data tersebut diambilkan dari suatu sampel yang mencerminkan populasi, sehingga data yang diperoleh merupakan data yang normal karena diambil dengan metode sampel yang benar. Implikasinya data tersebut dapat diberlakaukan untuk setiap tempat yang memiliki karakteristik yang sesuai dengan populasi tempat diambilnya sampel.

Linier atau sering juga disebut dengan linieritas bermakna bahwa antara variabel $\mathrm{X}$ dan variabel $\mathrm{Y}$ memiliki hubungan yang linier dalam arti antar variabel tersebut memiliki hubungan fungsional atau kausal.

Tabel 1 : Rekapitulasi Validitas Instrumen Angket Pendidikan Keluarga

\begin{tabular}{|c|c|c|}
\hline No Butir & Koefisien Korelasi & Ket \\
\hline 1 & 0,609 & Valid \\
\hline 2 & 0,686 & Valid \\
\hline 3 & 0,652 & Valid \\
\hline
\end{tabular}


Suparman : Pengaruh Pendidikan Keluarga Terhadap Prestasi Belajar

\begin{tabular}{|c|c|c|}
\hline 4 & 0,511 & Valid \\
\hline 5 & 0,658 & Valid \\
\hline 6 & 0,759 & Valid \\
\hline 7 & 0,541 & Valid \\
\hline 8 & 0,643 & Valid \\
\hline 9 & 0,594 & Valid \\
\hline 10 & 0,662 & Valid \\
\hline 11 & 0,762 & Valid \\
\hline 12 & 0,760 & Valid \\
\hline 13 & 0,502 & Valid \\
\hline 14 & 0,545 & Valid \\
\hline 15 & 0,557 & Valid \\
\hline 16 & 0,536 & Valid \\
\hline 17 & 0,552 & Valid \\
\hline 18 & 0,521 & Valid \\
\hline 19 & 0,779 & Valid \\
\hline 20 & 0,723 & Valid \\
\hline 21 & 0,613 & Valid \\
\hline 22 & 0,549 & Valid \\
\hline 23 & 0,584 & Valid \\
\hline 24 & 0,706 & Valid \\
\hline 25 & 0,702 & Valid \\
\hline 26 & 0,552 & Valid \\
\hline 27 & 0,603 & Valid \\
\hline
\end{tabular}

Uji linieritas dilaksanakan dengan menggunakan program aplikasi Microsoft Office Excel 2007. Hasil yang diperoleh dari perhitungan uji linieritas pada lampiran 10 dapat diketahui bahwa harga $F_{\text {hitung }}$ sebesar 4,22 sedangkan harga $F_{\text {tabel }}$ sebesar 4,66. Hal tersebut berarti $F_{\text {hitung }}<F_{\text {tabel, }}$ sehingga dapat disimpulkan bahwa antara variabel $\mathrm{X}$ (Pendidikan Keluarga) dengan variabel Y (Prestasi Belajar) terdapat hubungan yang linier.

Berdasarkan perhitungan chi kuadrat ( $\mathrm{x}^{2}$ hitung) pada lampiran 8 diperoleh harga $\left(x^{2}\right.$ hitung) sebesar 7,721 . 
Sedangkan pada tabel chi kuadrat dengan derajat kebebasan $(\mathrm{dk})=6-1=5$ dan taraf kesalahan $5 \%$ didapatkan $\left(\mathrm{x}^{2}\right.$ tabel $)$ sebesar 11,070. Karena harga $\left(x^{2}\right.$ hitung $\left.=7,721\right)<\left(x^{2}\right.$ tabel $=$ 11,070), maka distribusi pendidikan keluarga normal.

Berdasarkan perhitungan chi kuadrat ( $\mathrm{x}^{2}$ hitung) pada lampiran 9 diperoleh harga ( $x^{2}$ hitung) sebesar 5,451. Sedangkan pada tabel chi kuadrat dengan derajat kebebasan $(\mathrm{dk})=5-1=4$ dan taraf kesalahan $5 \%$ didapatkan $\left(\mathrm{x}^{2}\right.$ tabel $)$ sebesar 9,488. Karena harga $\left(x^{2}\right.$ hitung $\left.=5,451\right)<\left(x^{2}\right.$ tabel $=$ $9,488)$, maka distribusi prestasi belajar peserta didik normal.

Hasil analisis regresi menunjukkan bahwa pengaruh variabel Pendidikan Keluarga (X) terhadap variabel Prestasi Belajar adalah sebesar 0,44911 dan dibulatkan menjadi 0,45.

Koefisien $\mathrm{R}^{2}$ sebesar 0,45 ini memberikan informasi bahwa pendidikan keluarga memiliki pengaruh sebesar $45 \%$ terhadap prestasi belajar peserta didik.

Koefisien $\mathrm{R}^{2}$ ini merupakan koefisien yang signifikan, hal ini ditunjukan dengan hasil analisis varians pada tabel 4 yang memperoleh nilai $\mathrm{F}$ sebesar 14,675 dengan taraf sifnifikansi $\mathrm{F}$ sebesar 0,0012. Dimana signifikansi F sebesar 0,0012 lebih kecil dari 0,05.

Tabel 2. Rekapitulasi Validitas Instrumen Angket Prestasi Belajar Peserta Didik

\begin{tabular}{|c|c|c|}
\hline No Butir & $\begin{array}{c}\text { Koefisien } \\
\text { Korelasi }\end{array}$ & Ket \\
\hline 1 & 0,500 & Valid \\
\hline 2 & 0,581 & Valid \\
\hline 3 & 0,659 & Valid \\
\hline 4 & 0,685 & Valid \\
\hline 5 & 0,539 & Valid \\
\hline 6 & 0,696 & Valid \\
\hline 7 & 0,576 & Valid \\
\hline
\end{tabular}


Suparman : Pengaruh Pendidikan Keluarga Terhadap Prestasi Belajar

\begin{tabular}{|c|c|c|}
\hline 8 & 0,598 & Valid \\
\hline 9 & 0,738 & Valid \\
\hline 10 & 0,713 & Valid \\
\hline 11 & 0,713 & Valid \\
\hline 12 & 0,579 & Valid \\
\hline 13 & 0,627 & Valid \\
\hline 14 & 0,614 & Valid \\
\hline 15 & 0,571 & Valid \\
\hline 16 & 0,575 & Valid \\
\hline 17 & 0,587 & Valid \\
\hline 18 & 0,680 & Valid \\
\hline 19 & 0,834 & Valid \\
\hline 20 & 0,631 & Valid \\
\hline 21 & 0,631 & Valid \\
\hline 22 & 0,660 & Valid \\
\hline 23 & 0,538 & Valid \\
\hline 24 & 0,720 & Valid \\
\hline 25 & 0,846 & Valid \\
\hline 26 & 0,752 & Valid \\
\hline 27 & 0,882 & Valid \\
\hline 28 & 0,589 & Valid \\
\hline 29 & 0,682 & Valid \\
\hline 30 & 0,608 & Valid \\
\hline 31 & 0,700 & Valid \\
\hline
\end{tabular}

Tabel 3 : Analisis Regresi

\begin{tabular}{|l|l|}
\hline \multicolumn{2}{|c|}{ Regression Statistics } \\
\hline Multiple R & 0,670159878 \\
\hline R Square & 0,449114262 \\
\hline $\begin{array}{l}\text { Adjusted } \\
\text { Square }\end{array}$ & 0,418509499 \\
\hline Standard Error & 11,63930902 \\
\hline Observations & 20 \\
\hline
\end{tabular}




\section{G. Kesimpulan}

Bedasarkan hasil penelitian dapat disimpulkan bahwa pendidikan keluarga mempengaruhi keberhasilan pendidikan peserta didik sebesar $45 \%$ adapun sebesar $55 \%$ ditentukan oleh faktor lain yang tidak diteliti pada penelitianini.

Tabel 4 : Analisis Variansi

\begin{tabular}{|l|r|c|c|c|c|}
\hline & $d f$ & $S S$ & \multicolumn{1}{c|}{$M S$} & $F$ & Sig F \\
\hline Reg & 1 & 1988 & 1988 & 14,6 & 0,001 \\
\hline Res & 18 & 2438 & 135 & & \\
\hline Tot & 19 & 4426 & & & \\
\hline
\end{tabular}

Perhatian keluarga terhadap pendidikan di rumah akan sangat mempengaruhi keberhasilan pendidikan di Sekolah. Hal ini menegaskan kembali bahwa pendidikandirumah merupakan lingkungan pendidikan yang pertama dan utama bagi setiap peserta didik.

Keterlibatan pemangku kepentingan seperti kepala desa, kepala dusun sampai dengan ketua RW dan ketua RT sangat menentukan tersosialisasinya konsep bahwa pemahaman pendidikan keluarga memberikan pengaruh yang signifikan pada keberhasilan bagi peserta didik. 


\section{DAFTAR PUSTAKA}

Abdul Majid Khon, Hadis Tarbawi, Jakarta: Kencana Prenada Media Grup, 2012.

Abu Ahmadi dan Nur Uhbiyati, Ilmu Pendidikan, Jakarta: Rineka Cipta, 2015.

Eko Putro Widoyoko, Teknik Penyusunan Instrumen Penelitian, Yogyakarta: Pustaka Pelajar, 2014

Helmawati, Pendidikan Keluarga, Bandung: PT Remaja Rosdakarya, 2014

Jalaluddin, Psikologi Agama, Jakarta: PT RajaGrafindo Persada, 2010.

Lilik Sriyanti, Psikologi Belajar, Yogyakarta: Ombak, 2013.

Margono, Metodologi Penelitian Pendidikan, Jakarta: Rineka Cipta, 2004.

Muhibbin Syah, Psikologi Pendidikan, Bandung: PT Remaja Rosdakarya, 2014.

Nur Ahid, Pendidikan Keluarga dalam Perspektif Islam, Jakarta: Pustaka Pelajar, 2010.

Safrudin Aziz, Pendidikan Keluarga Konsep dan Strategi, Yogyakarta: Gava Media, 2015.

Sri Lestari, Psikologi Keluarga, Jakarta: Kencana, 2014.

Sugiyono, Metode Penelitian Kombinasi, Bandung: Alfabeta, 2012.

Sugiyono, Statistika untuk Penelitian, Bandung: Alfabeta, 2013.

Suharsimi Arikunto, Prosedur Penelitian Suatu Pendekatan Praktik, Jakarta: Rineka Cipta, 2010.

Syaiful Bahri Djamarah, Psikologi Belajar, Jakarta: PT Rineka Cipta, 2011.

Syamil Al-Qur'an, Al-Qur'anul Karim, Bandung: Sygma Examedia Arkanleema, 2009. 
Suparman : Pengaruh Pendidikan Keluarga Terhadap Prestasi Belajar

Tohirin, Psikologi Pembelajaran Pendidikan Agama Islam, Jakarta: Raja Grafindo Persada, 2011.

Widodo Supriyono, Psikologi Belajar, Jakarta: PT Rineka Cipta, 2013.

Zuhairini, Filsafat Pendidikan Islam, Jakarta: Bumi Aksara, 2009. 